\title{
Relationships between early-life growth, intake, and birth season with first-lactation performance of Holstein dairy cows
}

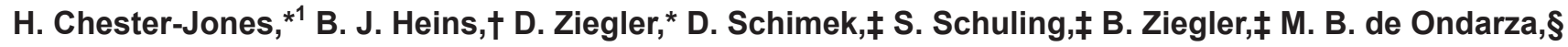 \\ C. J. Sniffen,\# and N. Broadwaterll \\ *University of Minnesota Southern Research and Outreach Center (SROC), Waseca 56093 \\ †University of Minnesota West Central Research and Outreach Center, Morris 56267 \\ łHubbard Feeds Inc., Mankato, MN 56001 \\ §Paradox Nutrition LLC, West Chazy, NY 12992 \\ \#Fencrest LLC, Holderness, NH 03245 \\ IIUniversity of Minnesota Extension Service Emeritus, Rochester 55904
}

\section{ABSTRACT}

The objective was to determine the relationships between early-life parameters [including average daily gain (ADG), body weight (BW), milk replacer intake, starter intake, and birth season] and the first-lactation performance of Holstein cows. We collected data from birth years 2004 to 2012 for 2,880 Holstein animals. Calves were received from 3 commercial dairy farms and enrolled in 37 different calf research trials at the University of Minnesota Southern Research and Outreach Center from 3 to 195 d. Upon trial completion, calves were returned to their respective farms. Milk replacer options included varying protein levels and amounts fed, but in the majority of studies, calves were fed a milk replacer containing $20 \%$ crude protein and $20 \%$ fat at $0.57 \mathrm{~kg} /$ calf daily. Most calves (93\%) were weaned at 6 wk. Milk replacer dry matter intake, starter intake, $\mathrm{ADG}$, and $\mathrm{BW}$ at 6 wk were $21.5 \pm 2.2$ $\mathrm{kg}, 17.3 \pm 7.3 \mathrm{~kg}, 0.53 \pm 0.13 \mathrm{~kg} / \mathrm{d}$, and $62.4 \pm 6.8$ $\mathrm{kg}$, respectively. Average age at first calving and firstlactation 305-d milk yield were $715 \pm 46.5 \mathrm{~d}$ and 10,959 $\pm 1,527 \mathrm{~kg}$, respectively. We conducted separate mixedmodel analyses using the REML model-fitting protocol of JMP (SAS Institute Inc., Cary, NC) to determine the effect of early-life BW or ADG, milk replacer and starter intake, and birth season on first-lactation 305$\mathrm{d}$ milk, fat, and true protein yield. Greater BW and $\mathrm{ADG}$ at 6 wk resulted in increased first-lactation milk and milk component yields. Intake of calf starter at 8 wk had a significant positive relationship with firstlactation 305-d yield of milk and milk components. Milk replacer intake, which varied very little in this data set, had no effect on first-lactation 305-d yield of milk and milk components. Calves born in the fall and

Received October 29, 2016.

Accepted January 22, 2017.

${ }^{1}$ Corresponding author: chest001@umn.edu winter had greater starter intake, BW, and ADG at 8 wk. However, calves born in the summer had a higher 305-d milk yield during their first lactation than those born in the fall and winter. Improvements were modest, and variation was high, suggesting that additional factors not accounted for in these analyses affected firstlactation performance.

Key words: calf, early-life growth, first-lactation yield

\section{INTRODUCTION}

Excellent colostrum and disease management, hygiene, milk replacer quality and consumption, calf starter quality and consumption, water quality and access, and postweaning nutrition are all necessary to achieve optimal heifer growth and future milk production. During the past decade, higher levels of milk or milk replacer have been recommended to attain greater preweaning ADG, improve immune function, advance calf welfare, and increase first-lactation performance (Khan et al., 2011; Soberon et al., 2012). Preweaning ADG had a significant positive effect on first-lactation performance: every $100 \mathrm{~g}$ of preweaning ADG was associated with 85 to $111.3 \mathrm{~kg}$ more milk during the first lactation (Soberon et al., 2012). First-lactation yield of $4 \%$ FCM was $7.1 \%$ higher in calves fed whole milk rather than milk replacer $(0.81$ vs. $0.73 \mathrm{~kg}$ of ADG at 60 d; Moallem et al., 2010).

Several studies have observed no positive first-lactation response with intensified milk or milk replacer feeding. Davis Rincker et al. (2011) fed calves intensified versus conventional diets (0.68 vs. $0.45 \mathrm{~kg}$ of ADG) but observed no effect on 12 wk BW, calving BW and withers height, or first-lactation 305-d ECM yield. Holstein calves fed $8 \mathrm{~L}$ versus $4 \mathrm{~L}$ whole milk/d achieved higher ADG at $56 \mathrm{~d}(0.78$ vs. $0.62 \mathrm{~kg})$, but showed no differences in BW at 12 mo, age at first calving, or first-lactation performance (Kiezebrink et al., 2015). Holstein heifers on intensive versus conventional milk 
replacer programs (0.71 vs. $0.63 \mathrm{~kg}, 8$-wk ADG) had similar projected 305-d ME milk yield (Raeth-Knight et al., 2009).

A meta-analysis by Gelsinger et al. (2016) indicated that although preweaning ADG is positively related to first-lactation milk yield, factors other than preweaning intake and growth rate are more important in determining first-lactation performance. The adequacy of colostrum intake and immunoglobulins affects not only the health of the calf but also its subsequent growth rate and future productivity (Nocek et al., 1984; DeNise et al., 1989). Calf starter intake before weaning has been closely correlated with ADG during the week after weaning (Stamey et al., 2012). Weaning DMI has been positively related to first-lactation production (Heinrichs and Heinrichs, 2011). An analysis of over 231,000 records by Barash et al. (1996) determined that Holsteins in Israel, an environment more prone to summer heat stress, had the lowest production if they were born in the early spring and the highest production if they were born in the fall. Records analysis of 795 Pennsylvania Holsteins indicated that calves born in winter tended to have higher ADG, while those born in the summer had lower ADG (Place et al., 1998). Postweaning management and nutrition must also be considered. Hill et al. (2016) found that structural growth at $16 \mathrm{wk}$ was not affected by the amount of milk replacer provided during the first $8 \mathrm{wk}$ of life, since at $11 \mathrm{wk}$, calves previously fed high levels of milk replacer digested less OM. Shamay et al. (2005) fed calves ad libitum milk rather than milk replacer and achieved greater BW at $60 \mathrm{~d}$ ( 84 vs. $69.5 \mathrm{~kg}$ ) and higher $3.5 \%$ FCM during their first lactation. However, in this study, calves fed milk replacer and later supplemented with fish meal from 180 to $270 \mathrm{~d}$ had a $3.5 \%$ FCM yield similar to those fed ad libitum milk.

Based on previous findings, we hypothesized that improvements in preweaning ADG would be associated with greater first-lactation milk yield. The objective of this study was to determine the relationships between early-life growth, intake, and birth season with firstlactation performance in Holstein dairy cows that were received as calves from 3 commercial dairy farms and enrolled in calf research trials at the University of Minnesota Southern Research and Outreach Center.

\section{MATERIALS AND METHODS}

\section{Calf Management and Data Collection}

Data were collected from birth years 2004 to 2012 for 2,880 Holstein animals. Calves were contract-raised for
3 commercial dairy farms, which represented over 2,000 dairy cows. Heifer calves were picked up twice weekly at 2 to $5 \mathrm{~d}$ of age and taken to the University of Minnesota Southern Research and Outreach Center. On d 1 , blood samples were taken via jugular venipuncture and analyzed for total serum protein concentration using a hand-held refractometer (Spartan Refractometer, model A 300 CL; Spartan, Tokyo, Japan). Calves were enrolled in 37 different calf nursery studies at the University of Minnesota Southern Research and Outreach Center for this data set.

In each nursery study, calves were housed at the Southern Research and Outreach Center Calf and Heifer Research Facility in individual pens $(2.3 \times 1.2 \mathrm{~m})$ inside 2 curtain sidewall, naturally ventilated $(9 \times 61$ $\mathrm{m}$ ) barns. Barns contained 2 rooms with approximately 40 calves per room. Pens were bedded mainly with straw in the winter months and wood shavings in the summer months. Calves were cared for according to the University of Minnesota Institutional Animal Care and Usage Committee recommendations (current standard operating procedures \#1410B54891).

Milk replacer options included varying protein levels and amounts fed, but in the majority of studies in this data set, calves were fed a milk replacer (all milk protein or partial replacement with alternative protein sources) containing $20 \% \mathrm{CP}$ and $20 \%$ fat at $0.57 \mathrm{~kg} /$ calf daily. Moderate intensive or intensive milk replacer programs were evaluated with about $10 \%$ of the calves in the data set. Most calves (93\%) were weaned at 6 wk. Several studies focused on calf starter formulations and physical form as the main effects when calves were fed a milk replacer containing 20\% CP and 20\% fat. Feed intake, growth, feed efficiency, calf health, and treatments were documented for each study. Milk replacer intake was recorded daily until weaning. Calf starter was offered daily to maintain a $5 \%$ refusal rate, and refusals were recorded weekly. Body weights were recorded on d 1, 14, 28, 42, and 56, and hip heights on d 1 and 56. Routine practices, such as vaccinations and dehorning, were implemented.

At approximately 2 mo of age, heifers were moved from the nursery and grouped in $6.4-\mathrm{m} \times 2.7-\mathrm{m}$ pens with 6 to 8 heifers per pen for 112 d, in a naturally ventilated curtain sidewall barn. During the transition to group pens, heifers were offered the same calf starter as fed in the nursery for a few days, and then limitfed a $16 \% \mathrm{CP}$ (as-fed) grain mix at 2.27 to $2.73 \mathrm{~kg} /$ heifer daily. Hay and water were offered ad libitum. When heifers were between 6 and 7 mo of age, they were transferred to next-phase growers and returned to their respective dairy farms before calving. 


\section{Statistical Analysis}

Mixed model regression analysis was conducted using JMP statistical software (SAS Institute Inc., Cary, NC); early-life calf parameters were regressed on firstlactation responses. Separate mixed model analyses were conducted using the REML model-fitting protocol.

The effects of 6- and 8-wk BW, 6- and 8-wk ADG, and 6-wk ADG class $(<0.23,0.23-0.34,0.34-0.45$, $0.45-0.57,0.57-0.68,0.68-0.80$, and $>0.80 \mathrm{~kg} / \mathrm{d})$ on first-lactation 305-d milk, fat, and true protein yield were determined. For the 3 individual farms, the models included birth season, calving season, and calving year, with calf trial as a random effect. For analysis of all farms, we also included calving year nested within farm. Subsequent multiple comparisons by 6 -wk ADG class were performed with the Tukey's honest significant differences test.

The entire data set was used to further evaluate effects of calf intake and birth season. First, the effects of 8-wk milk replacer and calf starter DMI on firstlactation 305-d milk, milk fat, and true protein yield were evaluated. Second, the effects of birth season on 8-wk starter intake, 8-wk BW, 8-wk ADG, and firstlactation 305-d milk, milk fat, and true protein yields were determined. Birth season, calving season, calving year, and calving year nested within farm were included in the models with calf trial as a random effect. Eightweek ADG and 8-wk ADG $\times$ birth season were also included when evaluating first-lactation performance. Subsequent multiple comparisons by birth season were performed with the Tukey's honest significant differences test.

\section{RESULTS AND DISCUSSION}

Table 1 shows intake, BW, ADG, height, and firstlactation yield parameters (mean; SD) for the individual farms and all farms. The majority of calves were fed a milk replacer containing $20 \% \mathrm{CP}$ and $20 \%$ fat at $0.57 \mathrm{~kg} /$ calf daily. This milk replacer feeding rate was somewhat higher than what is considered conventional (10\% of BW), but not as high as "intensified or accelerated" programs (20\% of BW; Khan et al., 2011). For all farms, milk replacer DMI, starter intake, ADG, and BW at 6 wk were $21.5 \pm 2.2 \mathrm{~kg}, 17.3 \pm 7.3 \mathrm{~kg}, 0.53$ $\pm 0.13 \mathrm{~kg} / \mathrm{d}$, and $62.4 \pm 6.8 \mathrm{~kg}$, respectively. Average age at first calving and first-lactation 305-d milk yield were $715 \pm 46 \mathrm{~d}$ and $10,959 \pm 1,527 \mathrm{~kg}$, respectively. Because all calves were fed and managed in the same way, calf growth rates were similar, regardless of calves' farm of origin. As expected, we observed greater differences by farm in age at first calving $(714,702$, and $725 \mathrm{~d}$ for farms $\mathrm{A}, \mathrm{B}$, and $\mathrm{C}$, respectively) and first-

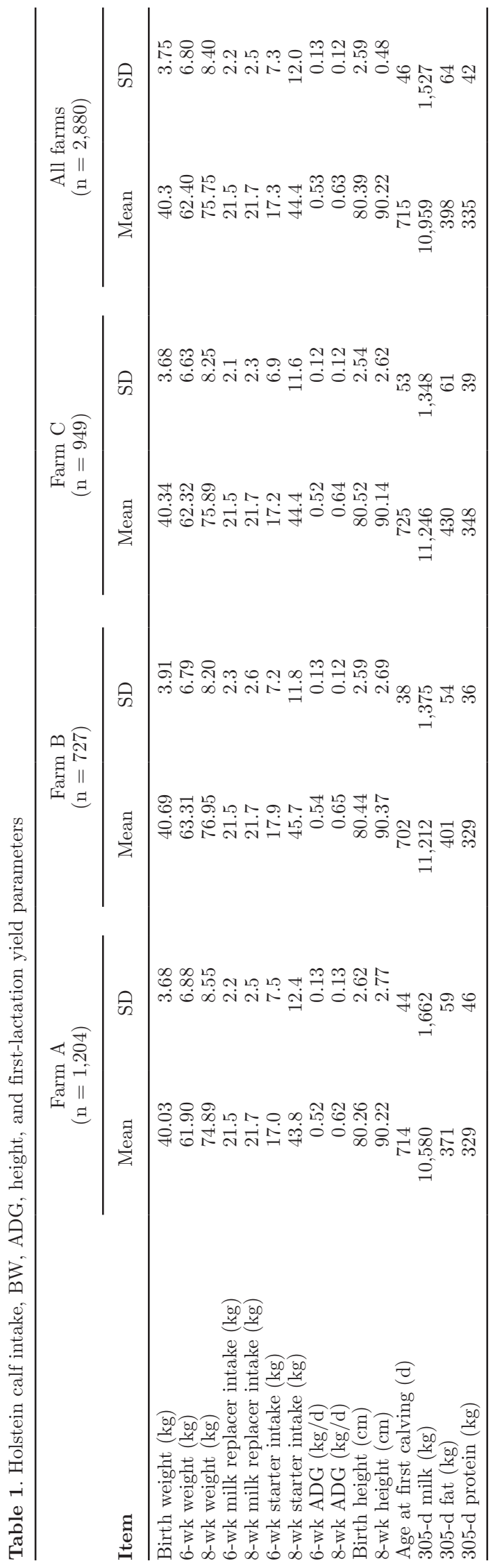

Journal of Dairy Science Vol. 100 No. 5, 2017 
lactation 305-d milk yield (10,580, 11,212, and 11,246 $\mathrm{kg}$ for farms A, B, and C, respectively).

\section{Early-Life Growth Versus First- Lactation Performance}

Initially, 305-d first-lactation milk yields were simply regressed on 6-wk calf growth rates without including other sources of variation in the statistical model. According to this analysis, 6-wk ADG significantly improved 305-d milk yield in the first lactation $(P=$ $0.05)$. For every $1 \mathrm{~kg}$ of ADG at $6 \mathrm{wk}, 305-\mathrm{d}$ milk yield improved by $456.25 \mathrm{~kg}$. However, despite the high level of significance we found, it is difficult to be confident in this prediction equation because of the high variation around the estimate $(\mathrm{SE}=229 \mathrm{~kg}$; Figure 1 ).

Further analyses investigated the effects of 6 - and 8-wk BW, 6- and 8-wk ADG, and 6-wk ADG class on first-lactation 305-d milk, fat, and true protein yields, and accounted for other sources of variation, including birth season, calving season, calving year, calf trial, and farm. Across all farms, BW at 6 and 8 wk and $\mathrm{ADG}$ at 6 and 8 wk were positively related to firstlactation 305-d milk, fat, and protein yield $(P<0.05$; Tables 2 and 3). For individual farms, ADG at 6 or 8 wk was not consistently related to first-lactation 305-d milk, fat, or protein yield (Table 2). Body weight at 6 or 8 wk was positively related to first-lactation $305-\mathrm{d}$ yield parameters for farms $\mathrm{A}$ and $\mathrm{C}(P<0.05)$ (Table 3). Generally, BW at 6 or 8 wk had a more reliable positive effect on first-lactation production than ADG. This makes sense, because BW also incorporates birth weight, which has a positive effect on first-lactation performance (Ghoraishy and Rokouei, 2013).

Based on regression estimates, every $1 \mathrm{~kg}$ of 6 -wk ADG was associated with $544 \mathrm{~kg}$ more first-lactation 305-d milk and every $1 \mathrm{~kg}$ of 8-wk ADG yielded 579 $\mathrm{kg}$ more first-lactation 305-d milk (Table 2). However, the standard errors associated with these estimates were high, at 249 and $241 \mathrm{~kg}$ for 6- and 8-wk ADG, respectively. Every $1 \mathrm{~kg}$ of 6 - and 8-wk BW resulted in 20.1 and $14.8 \mathrm{~kg}$ more first-lactation 305-d milk, respectively. But again, the standard errors were large, at 4.4 and $3.5 \mathrm{~kg}$, respectively (Table 3 ). Prediction estimates varied by farm and had even larger standard errors associated with them. It is difficult to use these estimates to predict future performance with confidence when the variation around these estimates is so high. This high variation suggests that additional factors not accounted for in these analyses affected first-lactation

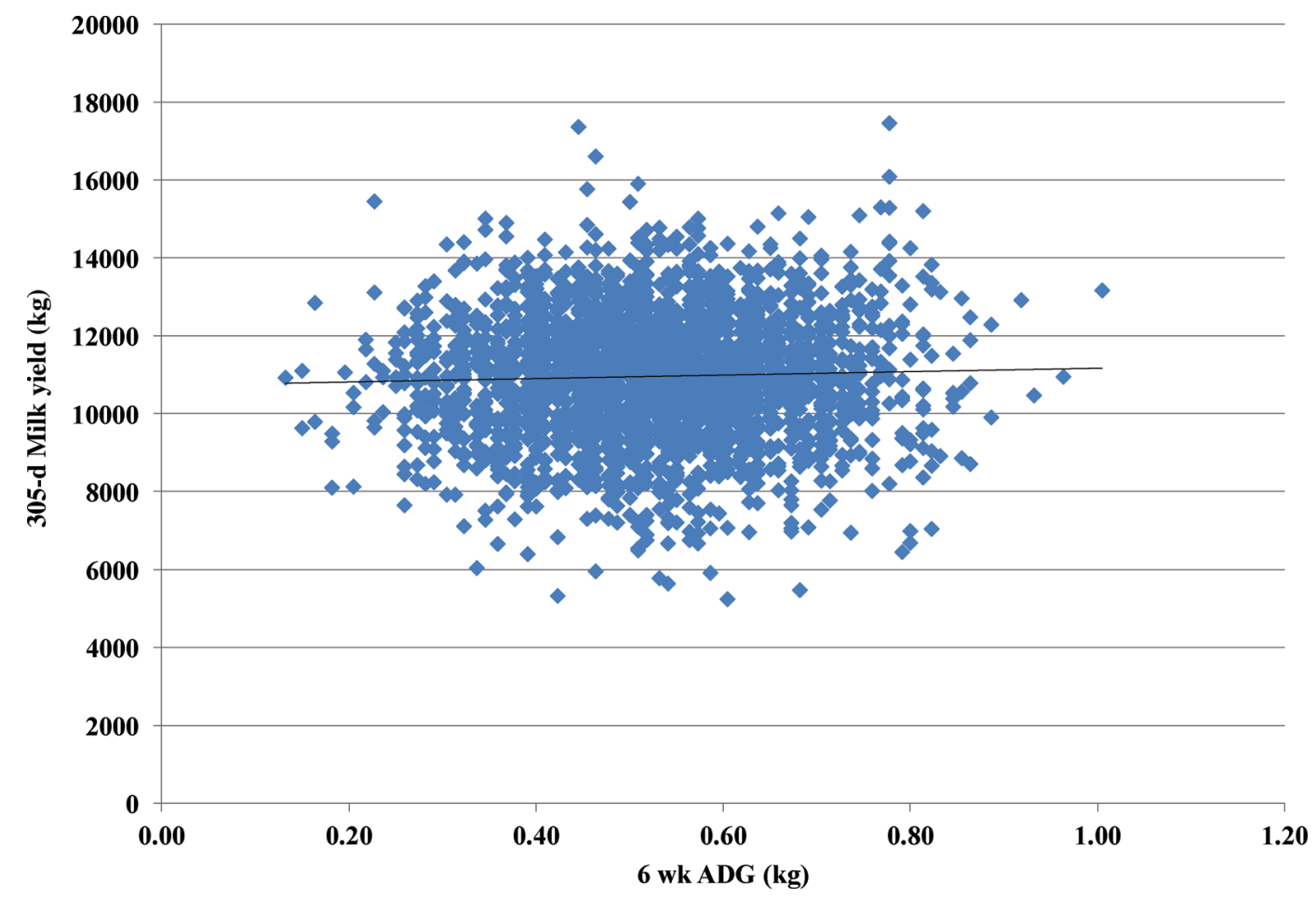

Figure 1. Relationship between 6-wk ADG $(\mathrm{kg})$ and first-lactation milk 305-d milk yield $(\mathrm{kg})$ with all calves $(\mathrm{n}=2,880)$. Color version available online. 
CALF GROWTH PARAMETERS VERSUS FIRST-LACTATION YIELD
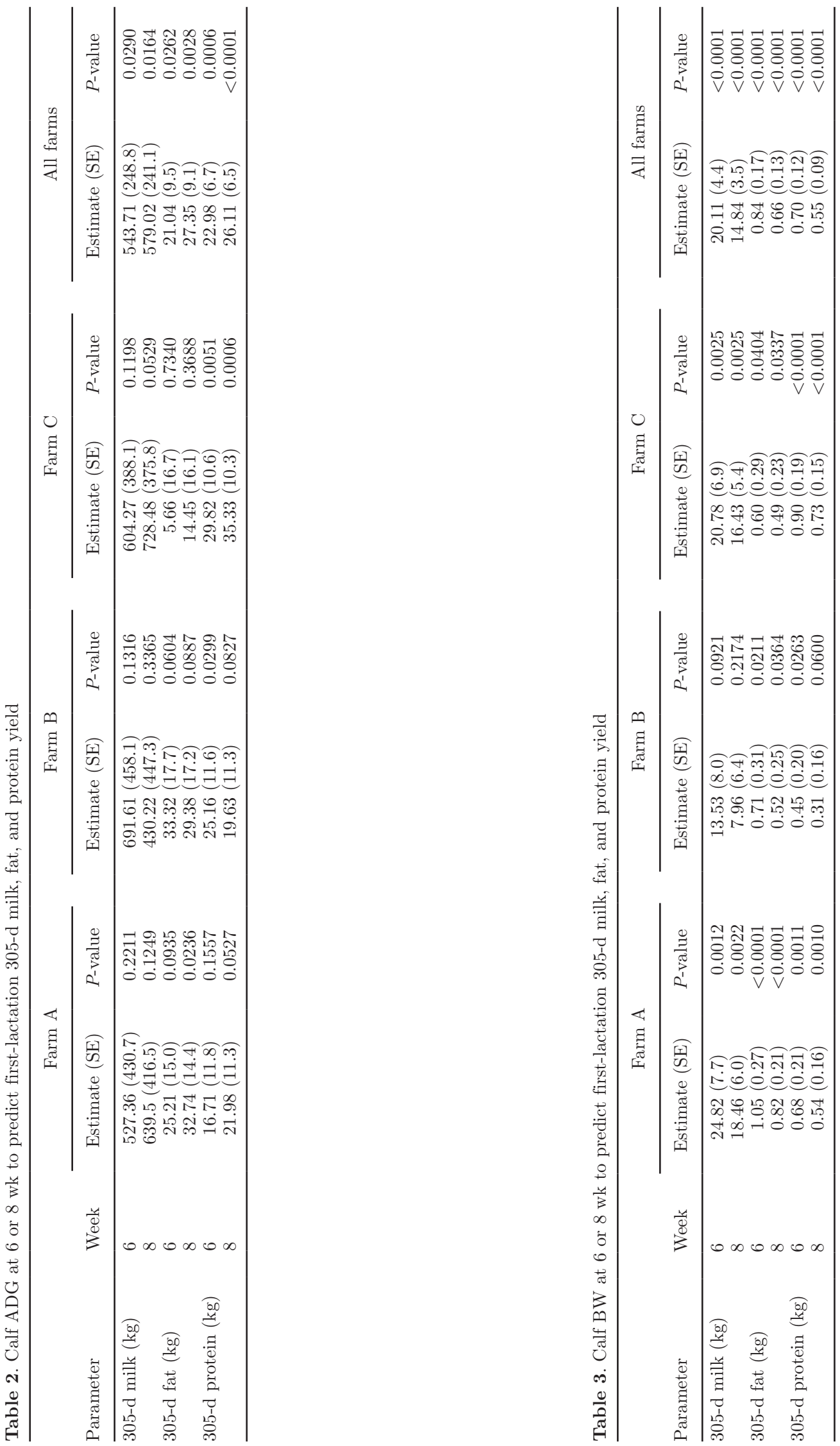

Journal of Dairy Science Vol. 100 No. 5, 2017 
performance. Gelsinger et al. (2016) also found that preweaning growth rate accounted for less than $3 \%$ of the variation in first-lactation milk yield.

Soberon et al. (2012) concluded that preweaning ADG had a significant positive effect on first-lactation performance. Every $100 \mathrm{~g}$ of preweaning ADG was associated with $85 \mathrm{~kg}$ more milk during the first lactation in the Cornell herd, which had a mean preweaning ADG of $0.82 \mathrm{~kg}(\mathrm{SD}=0.18)$. In a separate analysis of a commercial herd with a preweaning ADG of $0.66 \mathrm{~kg}$ $(\mathrm{SD}=0.11)$, every $100 \mathrm{~g}$ of preweaning ADG resulted in $111.3 \mathrm{~kg}$ more milk (Soberon et al., 2012). These researchers stressed that calves in their data sets were fed higher levels of milk replacer ( $44 \mathrm{~kg}$ by $49 \mathrm{~d}$ ) to achieve higher prepubertal growth than conventional milk and milk replacer strategies, and that this promoted first-lactation yields (Soberon et al., 2012). However, the mean 8 -wk ADG $(0.63 \mathrm{~kg} / \mathrm{d})$ of our data set was similar to the 7 -wk ADG $(0.66 \mathrm{~kg} / \mathrm{d})$ reported for their commercial herd. It is a concern that Soberon et al. (2012) reported no indicators of variation around the estimates for improved first-lactation milk yield based on preweaning $\mathrm{ADG}$, and no $\mathrm{R}^{2}$ values. The $\mathrm{ADG}$ at 6 wk $(<0.23,0.23-0.34,0.34-0.45,0.45-0.57,0.57-0.68$, $0.68-0.80$, and $>0.80 \mathrm{~kg} / \mathrm{d})$ affected $(P<0.03) 305-\mathrm{d}$ first-lactation milk, fat, and protein when all 3 farms were analyzed together. Overall, calves with an ADG of 0.68 to $0.80 \mathrm{~kg} / \mathrm{d}$ at 6 wk produced more first-lactation 305-d milk, fat, and protein than calves with an ADG of 0.45 to $0.57 \mathrm{~kg} / \mathrm{d}$ at $6 \mathrm{wk}$. Within farms, we detected no effect of ADG class at 6 wk on first-lactation milk yield (Table 4).

\section{Early-Life Calf Starter and Milk Replacer Intake Versus First-Lactation Performance}

Eight-week calf starter DMI had a significant positive relationship with first-lactation 305-d yield of milk and milk components $(P<0.01$; Table 5$)$ in the overall data set, where mean calf starter DMI was 44.4 $\mathrm{kg}(\mathrm{SD}=12.0$; Table 1). Each additional kilogram of calf starter DMI at 8 wk resulted in $8.21 \mathrm{~kg}(\mathrm{SE}=$ $2.53 \mathrm{~kg}$ ) more first-lactation 305-d milk yield (Table 5). Improvements were modest, and variation was high, suggesting that additional factors not accounted for in this analysis affected first-lactation performance. However, our results would agree with the conclusions of Heinrichs and Heinrichs (2011) that weaning DMI is positively related to first-lactation production. Milk replacer intake, which varied very little in this data set, had no detectable effect on first-lactation 305-d yield of milk and milk components (Table 5). A greater range in milk replacer intake in the data set might have shown

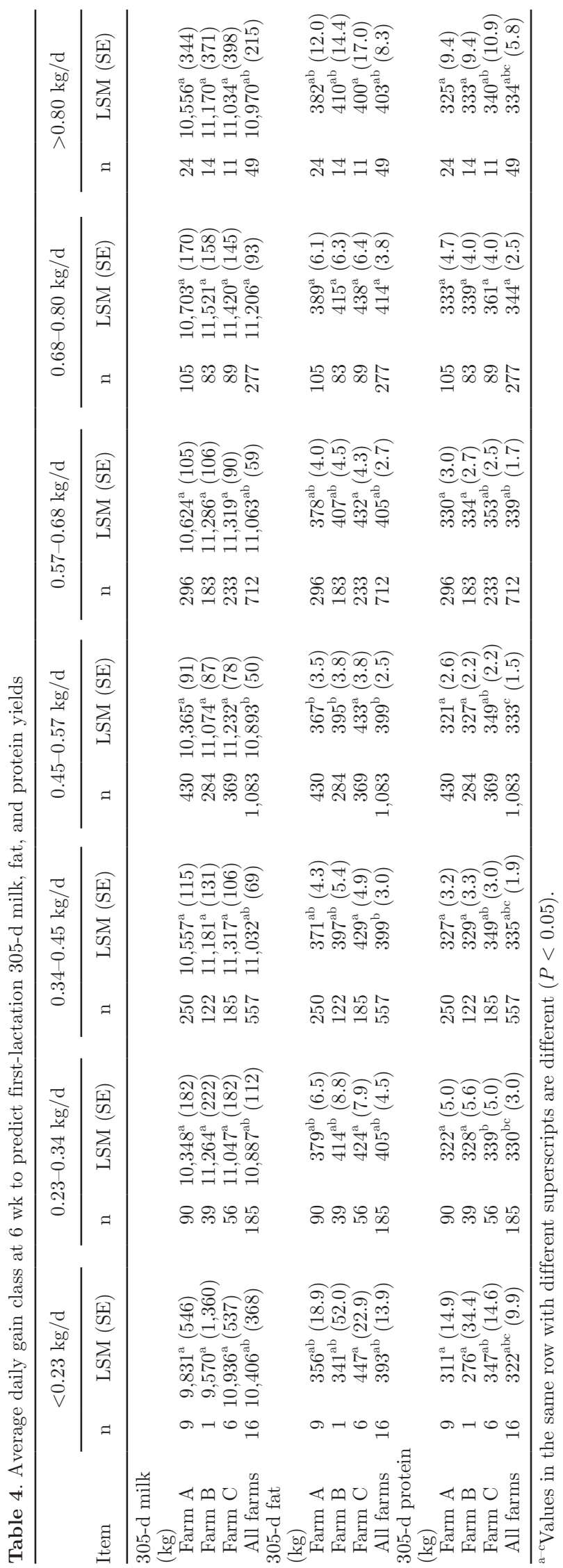


Table 5. Effect of 8-wk milk replacer $(\mathrm{kg})$ and calf starter $(\mathrm{kg})$ DMI on first-lactation 305-d milk, fat, and protein yields $(\mathrm{kg})$ in all calves $(\mathrm{n}=2,880)$

\begin{tabular}{lllrrr}
\hline Item & \multirow{2}{*}{$\mathrm{R}^{2}$} & Variable & Estimate & \multicolumn{1}{c}{$\mathrm{SE}$} & $P$-value \\
\hline 305-d milk & 0.10 & Milk replacer & 9.89 & 12.42 & 0.4261 \\
& & Calf starter & 8.21 & 2.53 & 0.0012 \\
305-d fat & \multirow{2}{*}{0.28} & Milk replacer & 0.52 & 0.53 & 0.3332 \\
\multirow{3}{*}{ 305-d protein } & & Calf starter & 0.36 & 0.10 & 0.0002 \\
& \multirow{2}{*}{0.17} & Milk replacer & 0.29 & 0.35 & 0.4115 \\
& & Calf starter & 0.33 & 0.07 & $<0.0001$ \\
\hline
\end{tabular}

Table 6. Effect of birth season on 8-wk starter intake $(\mathrm{kg}), \mathrm{BW}(\mathrm{kg})$, and ADG $(\mathrm{kg} / \mathrm{d})$ and on first-lactation 305-d milk, fat, and protein yield in all calves $(\mathrm{n}=2,880)$

\begin{tabular}{|c|c|c|c|c|c|}
\hline Item & $\begin{array}{c}\text { Birth season } \\
P \text {-value }\end{array}$ & Spring & Summer & Fall & Winter \\
\hline 8-wk calf starter DMI $(\mathrm{kg})$ & $<0.0001$ & $42.7^{\mathrm{b}}$ & $42.8^{\mathrm{b}}$ & $48.0^{\mathrm{a}}$ & $48.6^{\mathrm{a}}$ \\
\hline 8-wk BW $(\mathrm{kg} / \mathrm{d})$ & $<0.0001$ & $75.5^{\mathrm{b}}$ & $74.6^{\mathrm{b}}$ & $77.7^{\mathrm{a}}$ & $77.3^{\mathrm{a}}$ \\
\hline 305-d milk (kg) & 0.0206 & $11,033^{\mathrm{ab}}$ & $11,145^{\mathrm{a}}$ & $10,875^{\mathrm{b}}$ & $10,863^{\mathrm{b}}$ \\
\hline $305-\mathrm{d}$ fat $(\mathrm{kg})$ & 0.0508 & $401^{\mathrm{ab}}$ & $409^{\mathrm{a}}$ & $401^{\mathrm{ab}}$ & $397^{\mathrm{b}}$ \\
\hline 305 -d protein $(\mathrm{kg})$ & 0.0343 & $336^{\mathrm{ab}}$ & $340^{\mathrm{a}}$ & $333^{\mathrm{ab}}$ & $332^{\mathrm{b}}$ \\
\hline
\end{tabular}

${ }^{\mathrm{a}, \mathrm{b}}$ Values in the same row with different superscripts are different $(P<0.05)$.

more impact on first-lactation 305-d yield of milk and milk components.

\section{Birth Season Versus Early-Life Starter Intake and Growth and First-Lactation Performance}

Calves born in fall and winter had greater $(P<0.05)$ starter intake (48.3 vs. $42.8 \mathrm{~kg})$, BW (77.5 vs. $75.1 \mathrm{~kg})$, and ADG (0.66 vs. $0.63 \mathrm{~kg} / \mathrm{d}$ ) at 8 wk (Table 6). These results agreed with those of Place et al. (1998), who found that calves born in winter tended to have greater ADG than those born in other seasons.

Despite lower ADG at $8 \mathrm{wk}$, calves born in summer produced $276 \mathrm{~kg}$ more $305-\mathrm{d}$ milk during their first lactation than those born in the fall and winter $(P<0.05)$. Calves born in summer also produced 12 $\mathrm{kg}$ more 305-d fat and $8 \mathrm{~kg}$ more true protein than those born in winter $(P<0.05$; Table 6$)$. We observed no interaction between birth season and 8-wk ADG on first-lactation performance in this data set. The calves of Soberon et al. (2012) that were born in the summer produced $556 \mathrm{~kg}$ more first-lactation milk than calves born in the winter. However, contrary to our results, the calves of Soberon et al. (2012) had lower ADG in the winter; the authors surmised that this lower ADG and eventual poorer performance was related to the fact that calves born in the winter had greater maintenance requirements with cold temperatures. Obviously, given the higher winter ADG results observed in the present study, calves were meeting their energy needs. Other factors, including differences in photoperiod with season (Rius and Dahl, 2006), are likely to be important.

\section{CONCLUSIONS}

Calf BW and ADG at 6 and 8 wk had significant positive effects on 305-d first-lactation milk, fat, and true protein yield. Calf starter DMI at 8 wk also improved first-lactation performance, whereas milk replacer intake, which varied less in this data set, had no effect. Calves born in fall and winter had greater starter intake, BW, and ADG at 8 wk. However, calves born in summer produced more 305-d milk, fat, and true protein during their first lactation than those born in the fall and winter. Although we found high levels of significance, it was difficult to be confident in the prediction equations generated for calf growth parameters versus first-lactation performance. Improvements were modest and variation was high, suggesting that additional factors not accounted for in these analyses affected first-lactation performance.

\section{ACKNOWLEDGMENTS}

The authors express gratitude to workers at SROC for their assistance in data collection and care of animals. Financial support was provided for this project by Hubbard Feeds Inc. (Mankato, MN).

\section{REFERENCES}

Barash, H., N. Silanikove, and J. I. Weller. 1996. Effect of season of birth on milk, fat, and protein production of Israeli Holsteins. J. Dairy Sci. 79:1016-1020.

Davis Rincker, L. E., M. J. VandeHaar, C. A. Wolf, J. S. Leisman, L. T. Chapin, and M. S. Weber Nielsen. 2011. Effect of intensified 
feeding of heifer calves on growth, pubertal age, calving age, milk yield, and economics. J. Dairy Sci. 94:3554-3567.

DeNise, S. K., J. D. Robison, G. H. Stott, and D. V. Armstrong. 1989. Effects of passive immunity on subsequent production in dairy heifers. J. Dairy Sci. 72:552-554.

Gelsinger, S. L., A. J. Heinrichs, and C. M. Jones. 2016. A metaanalysis of the effects of preweaned calf nutrition and growth on first-lactation performance. J. Dairy Sci. 99:6206-6214.

Ghoraishy, S. H., and M. Rokouei. 2013. Impact of birth weight of Iranian Holstein calves on their future milk production and reproductive traits. J. Livestock Sci. Technol. 1:39-44.

Heinrichs, A. J., and B. S. Heinrichs. 2011. A prospective study of calf factors affecting first-lactation and lifetime milk production and age of cows when removed from the herd. J. Dairy Sci. 94:336-341.

Hill, T. M., J. D. Quigley, H. G. Bateman II, F. X. Suarez-Mena, T. S. Dennis, and R. L. Schlotterbeck. 2016. Effect of milk replacer program on calf performance and digestion of nutrients in dairy calves to 4 months of age. J. Dairy Sci. 99:8103-8110.

Khan, M. A., D. M. Weary, and M. A. G. von Keyserlingk. 2011. Invited review: Effects of milk ration on solid feed intake, weaning, and performance in dairy heifers. J. Dairy Sci. 94:1071-1081.

Kiezebrink, D. J., A. M. Edwards, T. C. Wright, J. P. Cant, and V. R. Osborne. 2015. Effect of enhanced whole-milk feeding in calves on subsequent first-lactation performance. J. Dairy Sci. 98:349-356.

Moallem, U., D. Werner, H. Lehrer, M. Zachut, L. Livshitz, S. Yakoby, and A. Shamay. 2010. Long-term effects of ad libitum whole milk prior to weaning and prepubertal protein supplementation on skel- etal growth rate and first-lactation milk production. J. Dairy Sci. 93:2639-2650.

Nocek, J. E., D. G. Braund, and R. G. Warner. 1984. Influence of neonatal colostrums administration, immunoglobulin, and continued feeding of colostrums on calf gain, health, and serum protein. J. Dairy Sci. 67:319-333.

Place, N. T., A. J. Heinrichs, and H. N. Erb. 1998. The effects of disease, management, and nutrition on average daily gain of dairy heifers from birth to four months. J. Dairy Sci. 81:1004-1009.

Raeth-Knight, M., H. Chester-Jones, S. Hayes, J. Linn, R. Larson, D. Ziegler, B. Ziegler, and N. Broadwater. 2009. Impact of conventional or intensive milk replacer programs on Holstein heifer performance through six months of age and during first lactation. J. Dairy Sci. 92:799-809.

Rius, A. G., and G. E. Dahl. 2006. Exposure to long-day photoperiod prepubertally may increase milk yield in first-lactation cows. J. Dairy Sci. 89:2080-2083.

Shamay, A., D. Werner, U. Moallem, H. Barash, and I. Bruckental 2005. Effect of nursing management and skeletal size at weaning on puberty, skeletal growth rate, and milk production during first lactation of dairy heifers. J. Dairy Sci. 88:1460-1469.

Soberon, F., E. Raffrenato, R. W. Everett, and M. E. Van Amburgh 2012. Preweaning milk replacer intake and effects on long-term productivity of dairy calves. J. Dairy Sci. 95:783-793.

Stamey, J. A., N. A. Janovick, A. F. Kertz, and J. K. Drackley. 2012 Influence of starter protein content on growth of dairy calves in an enhanced early nutrition program. J. Dairy Sci. 95:3327-3336. 